УДК 633.11:07.477-14

О. М. Ружицька, к.б.н., доцент

О. В. Борисова, аспірант

Одеський національний університет імені I. І. Мечникова, кафедра ботаніки, вул. Дворянська, 2, Одеса, 65082, Україна,

e-mail: flores@ukr.net, oljachum@gmail.com

\title{
РІСТ, ПРОДУКТИВНІСТЬ ТА ЯКІСТЬ ЗЕРНА ОЗИМОЇ СПЕЛЬТИ ЗА УМОВ ПІВДНЯ СТЕПОВОЇ ЗОНИ УКРАЇНИ
}

Рослини озимої плівчастої пшениці спельти (Triticum spelta L.) вирощували в польовому досліді за грунтово-кліматичних умов півдня степової зони. Досліджували особливості росту, формування листової поверхні, насіннєвої продуктивності та якості зерна. Проведена порівняльна характеристика визначених показників із аналогічними показниками сортів озимої м'якої пшениці (T. aestivum L.) степової зони України. Виявлено, що за умов агротехніки, традиційної для озимої пшениці в даному регіоні та кліматичних умов 20112012 років, дослідні зразки спельти пройшли всі фенологічні фази розвитку та мали насіннєву продуктивність колосу та рослини на 31-57 \% менше, ніж у сортів м'якої пшениці. Рослини спельти характеризувались більшими довжиною та масою вегетативної частини, площею та масою сирої речовини листя 3 однієї рослини, вмістом хлорофілу в листках. Зерно спельти відрізнялось, у порівнянні із м'якою пшеницею, більшим вмістом білка та іншим його біохімічним складом.

Ключові слова: спельта, Triticum spelta L., ріст, продуктивність, фотосинтетична поверхня, якість зерна, вміст білка.

Пшениця спельта (T. spelta L.) - давній, майже зниклий з культури вид. Генетично - це гексаплоїдна пшениця з геномним складом, гомологічним до м'якої пшениці. В теперішній час в багатьох країнах Європи відмічається збільшення інтересу до цієї культури, зростають площі ії вирощування. Підвищена увага до спельти зумовлена низкою факторів, серед яких можна назвати придатність до низькозатратного землеробства, а також харчові і технологічні переваги $[17,19,24]$. Останнім часом збільшується кількість публікацій, присвячених всебічному вивченню спельти: походженню виду, харчовим властивостям продукції, ідентифікації сортів, що вже вирощуються, придатності до органічного землеробства, впливу агроекологічних умов на продуктивні властивості [15, $18,25,29]$. В зв'язку з цим, актуальним $є$ вивчення зразків національних колекцій спельти з метою виявлення біологічних особливостей цієї культури, формування іï продуктивного та адаптивного потенціалу за різних умов вирощування [17]. В Україні комплексних досліджень з вивчення особливостей вирощування, функціонування рослин спельти, іiі стійкості до несприятливих чинників та формування продуктивності, майже не проводиться. У вітчизняній 
науковій літературі відсутні відомості щодо особливостей вирощування, функціонування та продуктивності рослин спельти в степовій зоні України. Відомо, що в умовах східного Лісостепу України вирощування існуючих сортів і форм озимої спельти значно обмежено через недостатню зимостійкість [9].

Як відомо, ріст та зернова продуктивність рослин $є$ інтегральними показниками їх життєдіяльності, що відображають стан рослин в конкретних умовах середовища, а якість зерна рослин залежить не лише від виду чи сорту, а й, значною мірою, від умов вирощування [25].

Метою роботи було вивчення біологічних особливостей та формування продуктивності рослин озимої плівчастої пшениці спельти (T. spelta L.) та їх порівняння з сортами озимої м'якої пшениці (Triticum aestivum L.) в умовах польового вирощування на півдні степової зони України.

В зв'язку з цим, були поставлені наступні задачі:

1. Визначити показники росту вегетативної частини рослин;

2. Визначити особливості формування листової поверхні рослин та вмісту хлорофілу в листках у фазі цвітіння;

3. Визначити показники насіннєвої продуктивності та якості зерна рослин у фазі повної стиглості.

\section{Матеріали та методи досліджень}

Рослини гексаплоїдної озимої плівчастої пшениці спельти (T. spelta L. var. duhamelianum) вирощували на дослідних ділянках відділу генетичних основ селекції Селекційно-генетичного інституту - Національного центру насіннєзнавства та сортовивчення (СГІ НЦНС) НААНУ (м. Одеса), територія якого розташована в південній частині Причорноморської низовини на півдні степової зони Одеської області. Насіння спельти отримали із колекції Національного центру генетичних ресурсів рослин України Інституту рослинництва ім. В. Я. Юр'єва НААН України. Спельта була представлена трьома зразками різного еколого-географічного походження Європейської групи, з номерами згідно національного каталогу: UA 0300306; UA 0300259; UA 0300101. Для порівняльної оцінки біологічних властивостей та морфо-біометричних показників спельти, за вказаних умов вирощування, використовували також рослини озимої м'якої пшениці (T. aestivum L.) двох сучасних високоврожайних сортів степової зони України - Куяльник і Селянка.

Представлені дані за результатами вирощування рослин в сезон 2011/2012 років, який характеризувався несприятливими погодними умовами для формування урожаю зернових культур: посуха восени, сильні зимові морози та відсутність сніжного покриву, а також аномальна тепла весна [12].

Насіння висівали широкорядним способом та вирощували рослини із дотриманням стандартних вимог агротехніки для озимої пшениці в даному регіо- 
ні. Облікова площа ділянок складала 5 м². Зволоження грунту відбувалось тільки за рахунок атмосферних опадів.

Спостереження за фенологічними фазами розвитку рослин проводили за традиційною методикою [3]. В фазі цвітіння визначали довжину головного пагону (ГП), вагу надземної частини та коренів рослин, площу, масу сирої та сухої речовини зелених листків, а також вміст в них хлорофілів. В фазі повної стиглості визначали морфометричні параметри колосу, а також показники насіннєвої продуктивності [5].

Довжину головного пагону вимірювали від прикореневої шийки до верхівки колосу. Для розрахунку площі листка визначали його довжину, найбільшу ширину, та враховували коефіцієнт, який визначали окремо для кожного виду або сорту. Площу листків розраховували також за ваговим методом [10]. Зразки для визначення фотосинтетичних пігментів відбирали у фазі цвітіння та молочної стиглості. Пігменти екстрагували із висічок прапорцевих листків в $96 \%$ етанолі. Вміст хлорофілу в листках визначали спектрофотометричним методом [7].

Зібране у фазі повної стиглості зерно спельти та м'якої пшениці тестували за показниками якості: вмістом білка (ISO 20483), твердозерністю (ISO 8611), вмістом розчинних в 50 \% 1-ізопропанолі білків, тестом Зелені (ISO 5529) та вмістом сухої клейковини (ISO 21415) [21, 22, 23].

У таблицях представлені середні арифметичні та їх стандартні похибки. Для оцінки достовірностей відмінностей середніх арифметичних за визначеними параметрами між різними генотипами використовували критерій Стьюдента [4]. Розрахунки проводили, використовуючи стандартний пакет програм Microsoft Excel 2007.

\section{Результати та їх обговорення}

3'ясування біологічних особливостей та формування продуктивності спельти, розробка та удосконалення технології іiі вирощування неможливі без вивчення та з'ясування особливостей росту, розвитку та функціональних особливостей життєдіяльності рослин даної культури в певних агро-кліматичних умовах середовища. Південь степової зони Одеської області характеризується недостатньою кількістю річних опадів, частими посухами навесні і високими середньорічними температурами. Дані літератури [16] свідчать, що спельта $€$ традиційною для більш прохолодних кліматичних зон із надлишковим зволоженням. Водночас відомо, що дана культура також успішно вирощується в різних країнах Європи та Азії.

Згідно з отриманими нами даними, рослини пшениці спельти усіх трьох зразків в польових умовах виявили здатність до перенесення умов зимівлі та посухи та нормально пройшли усі фенологічні фази розвитку, навіть за надзвичайно несприятливих метеорологічних умов 2011-2012 років. Спостереження за проходженням фенологічних фаз розвитку рослин після відновлення вегета- 
ції у весняний період до повної стиглості показало, що рослини пшениці спельти всіх зразків відрізнялись більш тривалою фазою весняного кущіння та пізнішими строками настання фаз «вихід в трубку», «цвітіння», а також відповідно і всіх фаз стиглості: «молочна», «воскова» та «повна», порівняно з рослинами м'якої пшениці сортів Селянка та Куяльник. Виявлені більш пізні строки настання виходу в трубку та цвітіння узгоджується 3 даними, наведеними в літературі для даного виду пшениці [1, 2, 27, 29].

Відмінності біометричних параметрів рослин сортів озимої пшениці T. aestivum L. та пшениці T. spelta L. у фазі цвітіння візуально добре помітні (рис. 1), вони відображені в табл. 1.

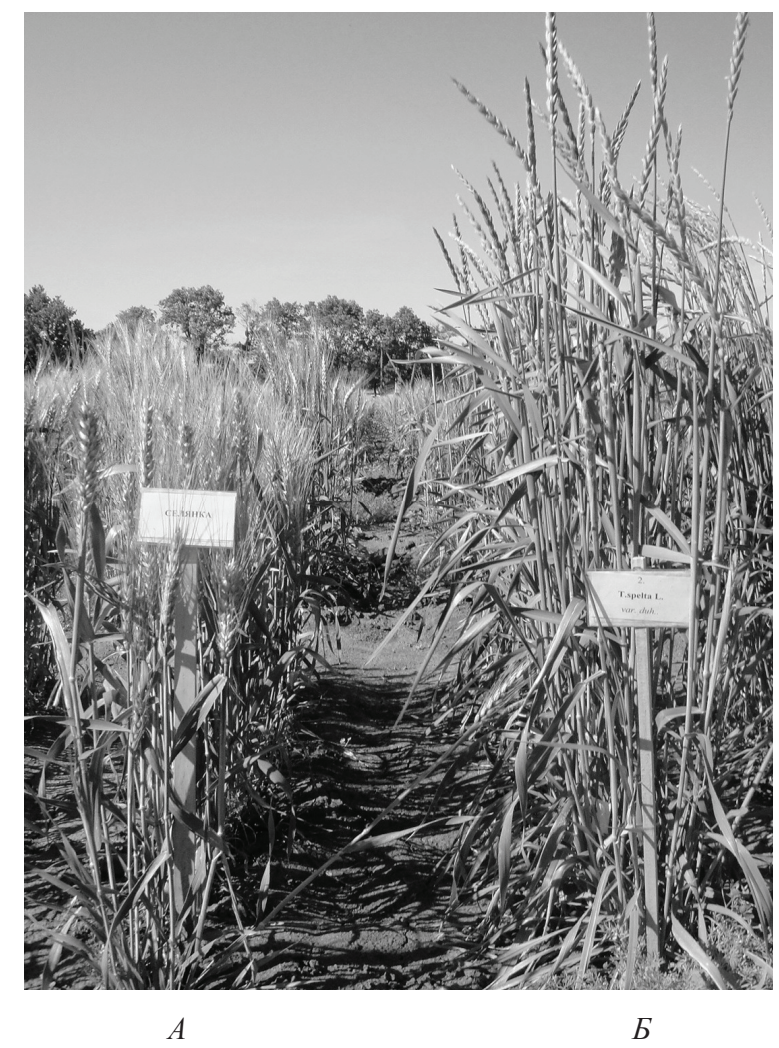

Pис. 1. Рослини озимої пшениці T. аеstivum L. (A) та T. spelta L. (Б) у фазі ивітіння

У фазі цвітіння всі зразки спельти відрізнялись достовірно більшими значеннями висоти рослин, маси сирої речовини надземної частини та коренів, у порівнянні із сортами м'якої пшениці, та не мали достовірних відмінностей між собою за даними параметрами (табл. 1). Відомо, що високорослість спельти $є$ характерною властивістю даного виду [29] та було показано результатами попередніх досліджень [14]. 
Слід відзначити, що середня висота рослин, як сортів м'якої пшениці, так і спельти, була дещо меншою, порівняно з середніми показниками за попередні роки, в зв'язку з несприятливими погодними умовами, зокрема посухою в період інтенсивного росту рослин.

Таблиця 1

Біометричні параметри рослин м'якої пшениці та пшениці спельти у фазі цвітіння

\begin{tabular}{|c|c|c|c|c|c|}
\hline \multirow[b]{2}{*}{ № } & \multirow{2}{*}{$\begin{array}{l}\text { Сорт, } \\
\text { зразок }\end{array}$} & \multirow{2}{*}{$\begin{array}{c}\text { Довжина головного } \\
\text { пагону (ГП), см }\end{array}$} & \multicolumn{2}{|c|}{ Вага сирої речовини, г } & \multirow{2}{*}{$\begin{array}{c}\text { Співвідношення } \\
\text { ваги коренів до } \\
\text { надземної частини }\end{array}$} \\
\hline & & & $\begin{array}{l}\text { Надземна } \\
\text { частина }\end{array}$ & Корінь & \\
\hline \multicolumn{6}{|c|}{ T. aestivum $\mathrm{L}$. } \\
\hline 1 & Селянка & $54,7 \pm 1,5$ & $25,7 \pm 1,9$ & $1,06 \pm 0,16$ & 0,041 \\
\hline 2 & Куяльник & $60,6 \pm 1,9$ & $17,9 \pm 1,6^{*}$ & $1,01 \pm 0,10$ & 0,056 \\
\hline \multicolumn{6}{|c|}{ T. spelta L. } \\
\hline 3 & UA 0300306 & $86,3 \pm 2,1 *$ & $29,3 \pm 2,7^{*}$ & $1,84 \pm 0,18^{*}$ & 0,063 \\
\hline 4 & UA 0300259 & $89,0 \pm 2,5^{*}$ & $28,5 \pm 2,5^{*}$ & $2,08 \pm 0,27 *$ & 0,073 \\
\hline 5 & UA 0300101 & $88,8 \pm 2,3^{*}$ & $28,1 \pm 2,4^{*}$ & $2,08 \pm 0,26^{*}$ & 0,074 \\
\hline
\end{tabular}

Примітка: * - відмінності достовірні у порівнянні з сортом Селянка при $\mathrm{p}<0,05$.

Площа листкової поверхні, тривалість життя зелених листків, вміст хлорофілу є важливими показниками функціонування рослин, що мають значення для формування його продуктивності, так як забезпечують потенційну потужність фотосинтетичного апарату та тривалішу їх роботу $[6,8,13]$. В той же час, стан листової поверхні відіграє важливу роль в процесах транспірації та газообміну рослини [11].

За результатами досліджень фотосинтетичного апарату було виявлено, що рослини усіх зразків спельти, порівняно з рослинами м'якої пшениці, мали меншу площу прапорцевого листка, однак більшу загальну площу листків однієї рослини та масу сирої речовини листків з однієї рослини (табл. 2). Водночас, більшою вагою сухої речовини листків з однієї рослини спельта не відрізнялась, що, як було виявлено, пов'язано з меншим відсотковим вмістом сухої речовини в її листках. В порівнянні з сортами м'якої пшениці, всі зразки плівчастої пшениці мали більший вміст в листках хлорофілу (у розрахунку на суху речовину) та достовірно не відрізнялись між собою, як в фазу цвітіння, так i молочної стиглості (рис. 2). 
Характеристика листової поверхні рослин пшениці

T. aestivum L. Ta T. spelta L. у фазі цвітіння

\begin{tabular}{|c|c|c|c|c|c|c|c|}
\hline \multirow[b]{2}{*}{ № } & \multirow{2}{*}{$\begin{array}{l}\text { Сорт, } \\
\text { зразок }\end{array}$} & \multicolumn{3}{|c|}{ Площа, см² $^{2}$} & \multirow{2}{*}{$\begin{array}{c}\text { Кіль- } \\
\text { кість } \\
\text { листків } \\
\text { рослини, } \\
\text { шт. }\end{array}$} & \multicolumn{2}{|c|}{$\begin{array}{c}\text { Маса листків } \\
\text { рослини, г }\end{array}$} \\
\hline & & $\begin{array}{l}\text { Прапорце- } \\
\text { вий листок }\end{array}$ & $\begin{array}{c}\text { Листки } \\
\text { головного } \\
\text { пагону }\end{array}$ & $\begin{array}{l}\text { Листки } \\
\text { рослини }\end{array}$ & & $\begin{array}{c}\text { Сира } \\
\text { речовина }\end{array}$ & $\begin{array}{c}\text { Суха } \\
\text { речовина }\end{array}$ \\
\hline \multicolumn{8}{|c|}{ T. aestivum $L$. } \\
\hline 1. & Селянка & $22,6 \pm 1,1$ & $41,7 \pm 1,9$ & $153,8 \pm 9,70$ & 12 & $1,78 \pm 0,3$ & $0,40 \pm 0,02$ \\
\hline 2. & Куяльник & $22,4 \pm 1,2$ & $41,9 \pm 2,1$ & $138,1 \pm 10,8$ & 11 & $1,74 \pm 0,1$ & $0,41 \pm 0,03 *$ \\
\hline \multicolumn{8}{|c|}{ T. spelta $L$. } \\
\hline 3. & UA 0300306 & $18,9 \pm 0,9 *$ & $39,7 \pm 1,4$ & $225,9 \pm 11,1^{*}$ & 16 & $3,89 \pm 0,4^{*}$ & $0,40 \pm 0,02$ \\
\hline 4. & UA 0300259 & $17,3 \pm 0,8^{*}$ & $56,2 \pm 1,7^{*}$ & $268,8 \pm 14,1^{*}$ & 23 & $4,11 \pm 0,3 *$ & $0,48 \pm 0,02^{*}$ \\
\hline 5. & UA 0300101 & $17,2 \pm 0,8^{*}$ & $42,9 \pm 2,1$ & $264,9 \pm 13,3^{*}$ & 18 & $4,20 \pm 0,3^{*}$ & $0,57 \pm 0,03 *$ \\
\hline
\end{tabular}

Примітка: * відмінності достовірні у порівнянні з сортом Селянка при $\mathrm{p}<0,05$.

Більший, порівняно з м'якою пшеницею, вміст хлорофілу в прапорцевому листку (мг/г сухої речовини), може свідчити як про певні відмінності в ультраструктурі фотосинтетичного апарату листка двох видів, так і в реакції фотосинтетичного апарату на певні умови навколишнього середовища, що може бути предметом подальших досліджень.

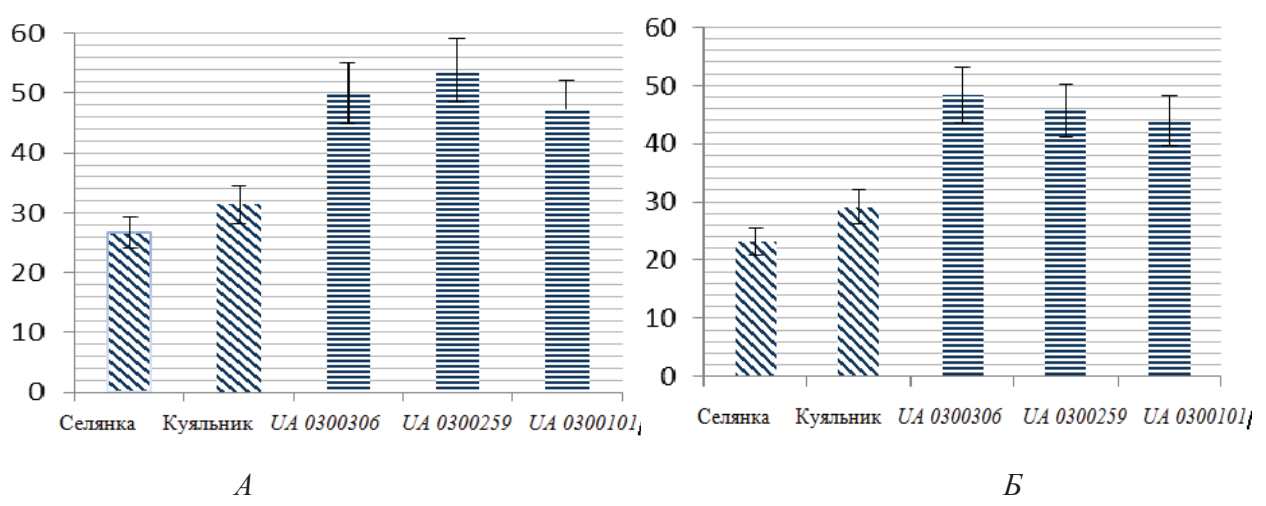

Рис. 2. Вміст хлорофілу (мг/2 сухої речовини) в прапориевих листках рослин пшениці T. aestivum L. ma T. spelta L. в фазі ивітіння (А) та молочної стиглості (Б) 
Відомо, що плівчасті співродичі культурних пшениць, зокрема пшениця спельта (T. spelta L.), привертають все більше уваги у світі завдяки високим харчовим цінностям зерна, а також своїй невибагливості до родючості грунтів, природній стійкості до шкідників, що робить їх придатними для органічного фермерства. Водночас відомо, що плівчасті співродичі м'якої пшениці, у порівнянні із сучасними ії сортами, характеризуються набагато нижчою врожайністю [24]. Саме це вказується як одна з причин, через яку в сучасному світі вона обробляється лише обмежено.

У фазі повної стиглості колоси спельти відрізнялись від сортів м'якої пшениці більшою довжиною та відсутністю остів, що $є$ цілком закономірним для даних видів. За числом колосків у колосі м'яка пшениця та пшениця спельта між собою суттєво не відрізнялись (рис. 3, табл. 3).

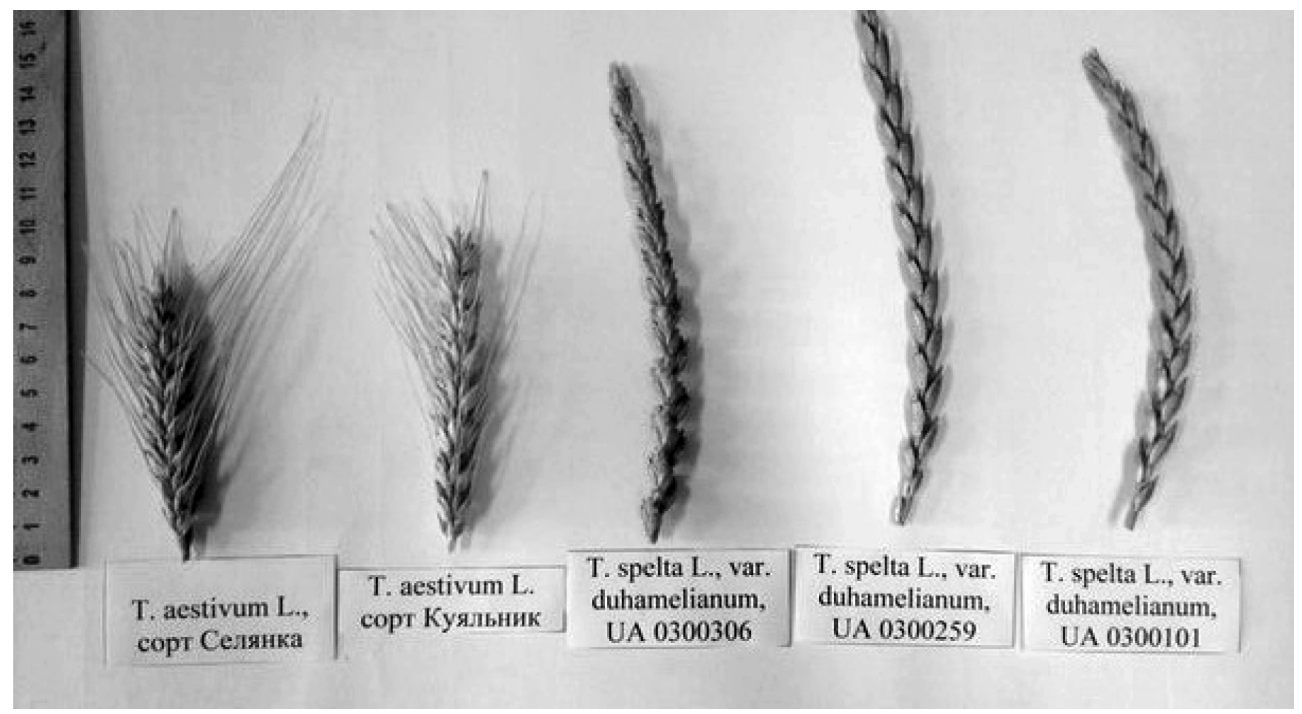

Рис. 3. Колоси сортів озимої м'якої пшениці

T. aеstivum L. та зразків спельти T. spelta L. у фазі повної стиглості.

Рослини спельти всіх проаналізованих зразків, за вказаних умов вирощування, поступались (на 31-57 \%) сортам Куяльник та Селянка за масою зерен у колосі головного пагону (табл. 3). Ці дані узгоджуються з літературними, де вивчалась продуктивність спельти за вирощування у різних регіонах $[24,29]$.

Для зерна спельти та для м'якої пшениці було визначено основні характеристики якості: твердозерність, вміст білка, сухої клейковини, розчинних у $50 \%$ 1-ізопропанолі фракцій білка, визначено значення за тестом Зелені (табл. 4). 
Таблиця 3

Морфометричні показники та насіннєва продуктивність колосу пшениці T. aestivum L. тa T. spelta L. у фазі повної стиглості

\begin{tabular}{|c|c|c|c|c|c|c|c|}
\hline № & Сорт, зразок & $\begin{array}{c}\text { Довжина } \\
\text { колосу } \\
\text { головного } \\
\text { пагону, см }\end{array}$ & $\begin{array}{c}\text { Число } \\
\text { колосків } \\
\text { у колосі, } \\
\text { шт. }\end{array}$ & $\begin{array}{c}\text { Щільність } \\
\text { колосу, шт./ } \\
\text { см }\end{array}$ & $\begin{array}{c}\text { Кількість } \\
\text { зерен у } \\
\text { колосі } \\
\text { головного } \\
\text { пагону, шт. }\end{array}$ & $\begin{array}{c}\text { Маса } 1000 \\
\text { зерен, Г }\end{array}$ & $\begin{array}{c}\text { Вага зерен } \\
\text { у колосі } \\
\text { головного } \\
\text { пагону, г }\end{array}$ \\
\hline & \multicolumn{7}{|c|}{ T. aestivum $L$. } \\
\hline 1. & Селянка & $9,1 \pm 0,3$ & $18 \pm 1$ & $1,9 \pm 0,1$ & $57 \pm 2$ & $39,3 \pm 1,4$ & $2,26 \pm 0,27$ \\
\hline 2. & Куяльник & $9,1 \pm 0,3$ & $18 \pm 1$ & $1,9 \pm 0,2$ & $57 \pm 3$ & $41,5 \pm 0,9$ & $2,32 \pm 0,15$ \\
\hline \multicolumn{8}{|c|}{ T. spelta $L$. } \\
\hline 3. & UA 0300306 & $15,9 \pm 1,0^{*}$ & $20 \pm 2$ & $1,2 \pm 0,1^{*}$ & $73 \pm 6^{*}$ & $20,8 \pm 1,7 *$ & $1,56 \pm 0,36^{*}$ \\
\hline 4. & UA 0300259 & $15,3 \pm 1,5^{*}$ & $18 \pm 1$ & $1,2 \pm 0,1^{*}$ & $30 \pm 4 *$ & $41,9 \pm 0,9$ & $1,26 \pm 0,05 *$ \\
\hline 5. & UA 0300101 & $11,3 \pm 0,4^{*}$ & $18 \pm 1$ & $1,6 \pm 0,2^{*}$ & $28 \pm 1 *$ & $34,5 \pm 1,4^{*}$ & $0,98 \pm 0,09 *$ \\
\hline
\end{tabular}

Примітка: * відмінності достовірні у порівнянні з сортом Селянка при $\mathrm{p}<0,05$

Твердозерність $є$ важливою технологічною характеристикою якості зерна, що впливає на напрями його використання. За даним показником розрізняють твердозерні та м'якозерні сорти [26]. Згідно отриманих даних, твердозерність спельти була на 37-72 одиниць нижчою від такої сортів м'якої пшениці. Вміст білка у зерні пшениці спельти перевищував такий м'якої пшениці на 3,8-4,7 \%, що узгоджується із даними інших дослідників [28]. Хоча, слід відзначити, що в зв'язку з посухою в період вирощування, зерно обох сортів характеризувалось значно більшим вмістом білка, ніж в середньому по роках для сортів м'якої пшениці в даному регіоні.

Харчова цінність зерна зумовлена не лише кількістю білка, а й, значною мірою, його якістю. Вміст сухої клейковини у зерні спельти виявився до 7,6 \% вищім, ніж у м'якої пшениці. Розділення білків у ізопропанолі є чутливим методом для фракціонування мономерних (альбуміни, глобуліни та гліадіни) та полімерних білків клейковини [20]. Саме фракція відносно легкорозчинних білків визначає харчову цінність зерна для людини, в зв'язку з кращим його засвоєнням. Вміст розчинних у ізопропанолі білків був у зерні спельти у 2 рази вищий, ніж у зерні м’якої пшениці. Це може свідчити про те, що зерно спельти 
є більш багатим на мономерні білки, порівняно із м'якою пшеницею сучасних дослідних сортів. Значення тесту Зелені були нижчими для спельти, що є індикатором низької сили клейковини. Ці результати погоджуються з даними інших авторів [27, 28].

Таблиця 4

Біохімічні показники зерна спельти та м'якої пшениці у фазі повної стиглості

\begin{tabular}{|c|c|c|c|c|c|}
\hline \multirow{3}{*}{ Параметр } & \multicolumn{5}{|c|}{ Вид/сорт, зразок } \\
\hline & \multicolumn{2}{|c|}{ T. aestivum $\mathrm{L}$. } & \multicolumn{3}{|c|}{ T. spelta $\mathrm{L}$. } \\
\hline & Селянка & Куяльник & UA 0300306 & UA 0300259 & UA 0300101 \\
\hline Твердозерність, од. & 61 & 49 & -11 & 12 & 5 \\
\hline Вміст білка, \% & $16,0 \pm 0,1$ & $16,5 \pm 0,3$ & $20,1 \pm 0,1^{*}$ & $20,7 \pm 0,2 *$ & $19,8 \pm 0,1^{*}$ \\
\hline Тест Зелені, мл & 43 & 41 & 25 & 24 & 27 \\
\hline $\begin{array}{l}\text { Вміст сухої клейко- } \\
\text { вини, \% }\end{array}$ & $9,2 \pm 0,2$ & $9,7 \pm 0,3$ & $15,9 \pm 0,3$ & $14,9 \pm 0,1$ & $16,8 \pm 0,4$ \\
\hline $\begin{array}{l}\text { Вміст розчинного } \\
\text { у 1-ізопропанолі } \\
\text { білка, \% }\end{array}$ & $21,7 \pm 0,5$ & $25,8 \pm 0,6$ & $46,0 \pm 0,8$ & $55,0 \pm 0,4$ & $49,2 \pm 0,6$ \\
\hline
\end{tabular}

Примітка: * - різниця достовірна порівняно з сортом Селянка при $\mathrm{p}<0,05$

Отже, зерну спельти, зібраному у фазі повної стиглості, за вирощування на півдні степової зони Одеської області, були притаманні усі властивості показників якості зерна, які цінуються у цій культурі: більший, ніж у сучасних сортах пшениці загальний вміст білка, а також білка розчинної фракції, нижча за м'яку пшеницю твердозерність та більший вміст сухої клейковини.

\section{Висновки}

1. За складних метеорологічних умов для формування урожаю зернових сезону 2001-2012 року на півдні України, пшениця спельта (T. spelta L.) трьох вивчених зразків (UA 0300306; UA 0300259; UA 0300101) колекції Національного центру генетичних ресурсів рослин України Інституту рослинництва ім. В. Я. Юр'єва НААН України, виявила здатність до перенесення умов зимівлі, нормально проходячи усі фенологічні фази розвитку, притаманні онтогенезу пшениці.

2. У фазі цвітіння рослини спельти характеризувались, порівняно з рослинами м'якої пшениці, більшою висотою рослин, масою сирої речовини надземної частини та коренів, більшою площею листової поверхні 
на одну рослину при меншій площі кожного окремого листка, більшим вмістом хлорофілу у розрахунку на суху речовину.

3. У фазі повної стиглості рослини спельти відрізнялись меншою (на 31 $57 \%$ вагою зерен у колосі головного пагона та зерна з однієї рослини, порівняно з сортами. Водночас для зерна спельти були притаманні: більший, ніж у сортів м'якої пшениці, вміст загального білка та фракції розчинного білка, нижча твердозерність та більший вміст сухої клейковини.

Автори вдячні завідувачу відділу генетичних основ селекції Селекційногенетичного інституту - Національного центру насіннєзнавства та сортовивчення НААНУ доктору біологічних наук Рибалці Олександру Іллічу та молодшому науковому співробітнику Поліщуку Сергію Сергійовичу за сприяння при проведенні досліджень та надану допомогу при вирощуванні рослин.

\section{Список використаної літератури}

1. Дорофеев В. Ф. Пшеница мира / В. Ф. Дорофеев, М. М. Якубцинер, М. И. Руденко. - Л.: Колос, 1976. $488 \mathrm{c}$.

2. Культурная флора СССР: Т. 1: Пшеница / В. Ф. Дорофеев, О. Н. Коровина - Л.: Колос, 1979. - 346 с.

3. Куперман Ф. М. Морфофизиология растений / Ф. М. Куперман. - М.: Высшая школа, 1977. - 288 с.

4. Лакин Г. Ф. Биометрия / Г. Ф. Лакин. - М.: Высш. шк., 1990. - 352 с.

5. Насіння сільськогосподарських культур. Терміни та визначення: ДСТУ 2949-94. - Введ. 28.12.94. - К.: Держстандарт України, 1995. - 50 с.

6. Моргун В. В. Фізіолого-генетичні проблеми селекції рослин у зв'язку з глобальними змінами клімату / В. В. Моргун, Т. М. Шадчина, Д. А. Кірізій // Физиология и биохимия культурных растений. - 2006. T. 38, № 5. - C. 371-389.

7. Мусієнко М. М. Спектрофотометричні методи в практиці фізіології, біохімії та екології рослин / М. М. Мусієнко, Т. В. Паршикова, П. С. Славний. - К.: Фітосоціоцентр, 2001. - 200 с.

8. Моргун В. В., Кірізій Д. А. Перспективи та сучасні стратегії поліпшення фізіологічних ознак пшениці для підвищення іiі продуктивності // Физиология и биохимия культурных растений. -2012 . - 44, № 6. С. $463-483$.

9. Нінієва А. К. Перезимівля колекційних зразків та гібридів озимої спельти / А. К. Нінієва // Біологія: від молекули до біосфери: V міжнародна конференція молодих науковців, 22-25 листопада 2010 р.: Тез. докл. / Харківський національний університет імені В. Н. Каразіна. - Х., 2010. - С. 162-163.

10. Ничипорович А. А. Фотосинтетическая деятельность растений в посевах / А. А. Ничипорович, Л. Е. Строганова, С. Н. Чмора - М.: Изд-во АН СССР, 1961. - 34 с.

11. Полевой В. В., Саламатова Т. С. Физиология роста и развития растений / В. В. Полевой, Т. С. Саламатова - Л.: Изд-во Ленингр. Ун-та. - 1991. - 240 с.

12. Почвенно-климатические условия и основные факторы, лимитирующие урожайность озимой пшеницы в регионе деятельности Селекционно-генетического института [Електроний ресурс]: Селекційногенетичний інститут - Національний центр насіннєзнавства та сортовивчення НААНУ. - Режим доступа: http://sgi.od.ua/rus/st/53-pochvenno-klimaticheskie-usloviya-i-osnovnye.html

13. Прядкина Г. А. Связь между показателями мощности развития фотосинтетического апарата и зерновой продуктивностью озимой пшеницы в различные по погодным условиям / Г. А. Прядкина, Т. М. Шадчина // Физиология и биохимия культ. растений. - 2009. - 41, № 2. - С. 59-68.

14. Ружицька О. М. Показники росту та насіннєвої продуктивності рослин деяких гексаплоїдних видів роду Triticum / О. М. Ружицька, А. П. Заболотна // Вісник Одеського національного університету. Біологія. 2012. - Т. 17, Вип. 1-2 (26-27). - С. 46-57.

15. Boguslavskj R. L. Cultivated emmer is valuable germplasm for durum wheat breeding / R. L. Boguslavskij, O. V. Golik, T.T. Tkachenko // ClHEAM/ASFAC. - 2001. - V. 54. - P. 125-127.

16. Campbell K. G. Spelt: Agronomy, Genetics and Breeding / K. G. Campbell // Plant Breeding Reviews. Vol. 15. - Ed. J. Janick., 1997. - P. 187-213. 
17. Dahlstedt L. Spelt Wheat (Triticum aestivum ssp. Spelta (L.)): An alternative crop for ecological farming systems / L. Dahlstedt // In: «Spelt and Quina» - Working Group Meeting 24-25 October 1997. - Wageningen, the Netherlands, 1997. - P. 3-6.

18. Dvoràček $V$. Evaluation of protein fractions as biochemical markers for identification of spelt winter cultivars (Triticum spelta L.) / V. Dvořàček, V. Čurn // J. Plant Soil Environ. - 2003. - Vol. 3. - P. 99-105.

19. Elfun R. The possibilities for spelt cultivation in Norway / R. Elfun, M. Aasven // In: «Spelt and Quina» Working Group Meeting. - 24-25 October 1997. - Wageningen, the Netherlands. - 1997. - P. 7-13.

20. Fu B. X. Procedure for Isolating Monomeric Proteins and Polymeric Glutenin of Wheat Flour / B. X. Fu, H. D. Sapirstain // J. Cereal Chem. - 73 (1). - 1996. - P. 143-152.

21. ISO 20483 Cereals and pulses // Determination of the nitrogen content and calculation of the crude protein content - Kjeldahl method. -2006 .

22. ISO 21415-2 Wheat and wheat flour // Gluten content. - 2008.

23. ISO 5529 Wheat // Determination of sedimentation index - Zeleny test, International Organization for Standardization, 9. - 1992.

24. Jorgensen J. R. Yield and quality assessment of spelt (Triticum spelta L.) compared with winter wheat (Triticum aestivum L.) in Denmark / J. R. Jorgensen, C. C. Olsen // In: «Spelt and Quina» - Working Group Meeting, 24-25 October 1997. - Wageningen, the Netherlands. 1997. - P. 33-38.

25. Lacko-Bartosova M. Triticum spelta - a specialty grain for ecological farming systems / Lacko-Bartosova M., Korczyk-Szabo J., Razny R.// Research Journal of Agricultural Science. - 2010. - Vol. 42 (1). - P. $143-147$.

26. Morris F. Craig Puroindolines: the molecular genetic basis of wheat grain hardness / F. Morris // Plant Molecular Biology. - Vol. 48. -2002. - P. 633-647.

27. Oliveira J. A. North Spanish emmer and spelt wheat landraces: agronomical and grain quality characteristic evaluation / J. A. Oliveira // J. Plant Genet. Resour. - 2001. - P. 16-20.

28. Rüegger A. Performance of spelt (Triticum spelta L.) and wheat (Triticum aestivum L.) at two contrasting environmental conditions / A. Rüegger, H. Winzeler // Agron. Crop Science. - 170. - 1993. - P. 289-295.

29. Smolková H. Winter spelt wheat (Triticum spelta L.) grain proteins genetic markers / H. Smolková, Z. Gálová, E. Grecová // Chemical papers. - 1998. - Vol. 52. - P. 52-53.

Стаття надійшла до редакції 15.01.2015

\section{О. Н. Ружицкая, О. В. Борисова}

Одесский национальный университет имени И. И. Мечникова, кафедра ботаники,

ул. Дворянская, 2, Одесса, 65082, Украина

\section{РОСТ, ПРОДУКТИВНОСТЬ И КАЧЕСТВО ЗЕРНА ОЗИМОЙ СПЕЛЬТЫ В УСЛОВИЯХ ЮГА СТЕПНОЙ ЗОНЫ УКРАИНЫ}

\section{Резюме}

Растения озимой пленчатой пшеницы спельты (Triticum spelta L.) выращивали в полевом опыте в почвенно-климатических условиях юга степной зоны. Исследовали особенности роста, формирования листовой поверхности, семенной продуктивности и качества зерна. Проведена сравнительная характеристика определенных показателей с аналогичными показателями сортов мягкой озимой пшеницы (Triticum aestivum L.) степной зоны Украины. Выявлено, что в условиях агротехники, традиционной для озимой пшеницы в данном регионе и климатических условиях 2011-2012 годов, исследуемые образцы спельты прошли все фенологические фазы развития и имели семенную продуктивность колоса и растения на 31-57 \% меньше, чем сорта мягкой пшеницы. Растения спельты характеризовались большей длиной и массой вегетативной части, площадью и массой сырого вещества листьев с одного растения, содержанием 
хлорофилла в листьях. Зерно спельты отличалось, в сравнении с мягкой пшеницей, большим содержанием белка и его иным биохимическим составом.

Ключевые слова: спельта, Triticum spelta L., рост, продуктивность, фотосинтетическая поверхность, качество зерна, содержание белка.

\section{O. M. Ruzhitska, O. V. Borysova}

Odesa National Mechnykov University, Department of Botany,

2, Dvoryanska str., Odesa, 65082, Ukraine

\section{GROWTH, PRODUCTIVITY AND GRAIN QUALITY OF WINTER SPELT UNDER UKRAINIAN SOUTH STEPPE ZONE}

\section{Summary}

Plants of winter hulled wheat spelt (Triticum spelta L.) were grown in field experiment on soil and climatic conditions of southern steppe zone. The features of spelt plants growth, leaf surface formation, seed productivity and grain quality were studied. The comparative characteristics of determined indicators for spelt wheat and winter wheat species (Triticum aestivum L.) of Ukrainian steppe zone were provided. It was found that under traditional for the winter wheat farming in the studied region, and under given climatic conditions of 2011-2012 years, investigated spelt samples passed all phenological phases of development and had 31-57\% less seed productivity of ears and plants compared to winter wheat cultivars. Spelt plants were characterized by higher length and weight of vegetative parts of the plant, plant leaves size and fresh weight from one plant, chlorophyll content in leaves. Spelt grain had higher protein content with different biochemical composition compared to winter wheat one.

Key words: spelt, Triticum spelta L., wheat growth, productivity, photosynthetic surface area, grain quality, protein content. 